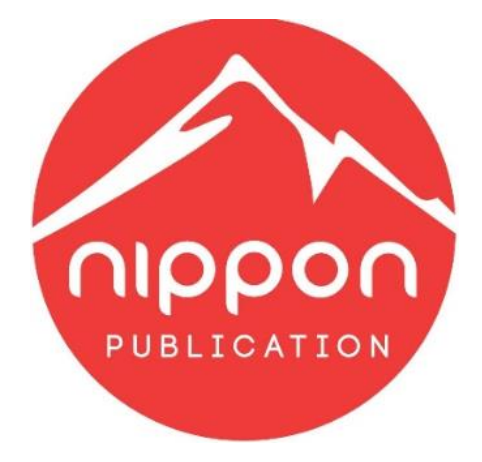

Nippon Journal of Environmental Science

ISSN: 2435-6786

1(6): 1016

https://doi.org/10.46266/njes.1016

Full Length Research Paper

\title{
Analysis of the recurrence of floods in the city of Tambacounda, Senegal, in the context of climate change
}

\author{
Mbagnick Faye ${ }^{1 *}$, Dome Tine ${ }^{2}$, Ababacar Fall ${ }^{3}$, Cheikh Sadibou Faye ${ }^{4}$, Gallo Niang ${ }^{5}$, Modou Mbaye ${ }^{6}$, Moctar \\ Diouf $^{7}$
}

${ }^{1}$ Laboratory of Climatology and Environment (LCE) - Department of Geography, Cheikh Anta DIOP University of DakarSenegal

${ }^{2}$ Department of Geography, Associate Researcher at the Applied Remote Sensing Laboratory (LTA) - Institute of Earth Sciences (IST), Cheikh Anta DIOP University in Dakar-Senegal. E-mail : dometine85@ gmail.com

${ }^{3}$ Water and Environmental Science and Technology Laboratory (WETL), Thiès Polytechnic, BP A10 Thiès, Senegal. Researcher associated with EA 7338 PLEIADE, University of Paris 13, 99 Jean Baptiste Clément Avenue, 93430 VILLETANEUSE

${ }^{4}$ Water and Environmental Science and Technology Laboratory (WETL), Thiès Polytechnic, BP A10 Thiès, Senegal

${ }^{5}$ Laboratory of Climatology and Environment (LCE) - Department of Geography, Cheikh Anta DIOP University of Dakar-

Senegal

${ }^{6}$ Institute of Applied Nuclear Technology, Associate Researcher at the Applied Remote Sensing Laboratory (LTA)- Institute of Earth Sciences (IST), Cheikh Anta DIOP University in Dakar- Senegal

${ }^{7}$ University of Paris 13, 99 Jean Baptiste Clément Avenue, 93430 VILLETANEUSE. Associate Researcher at the EA 7338 PLEIADE

*Corresponding Author: Email: fayedoudou85@yahoo.fr

Received 20 July 2020; Accepted 13 September 2020

\begin{abstract}
The climate is now subject to wide variations. Storms with torrential rains are noted in the western USA, acute droughts in the Sahel, floods in Bangladesh, China, India and Vietnam, and rising temperatures leading to thaws in the Arctic and Antarctic. Climate models and observations reveal the frequency of extreme events and the resumption of rains in recent years. This increase in rainfall, which brings hope to developing countries dependent on rain-fed agriculture, is upsetting African cities by the recurrence of the floods it generates. These cities, resembling large villages, lack everything: failure or lack of sanitation networks, lack of adequate urban policy. The city of Tambacounda is under-equipped and facing the problem of flooding. After the rain, housing, infrastructure and roads are submerged by storm water. Analysis of control strategies shows that serious measures are not being taken to eradicate this scourge in the city. The control techniques (totally incoherent and totally disorderly) developed by the population revolve around the filling of ravines and low parts (45\% of respondents), the installation of sandbags $(40 \%)$, serving as, the storefront of dwellings and digging trenches to facilitate storm runoff (15\%). The only reliable and effective technique (ONAS remediation plan) defined by the State is still in the draft stage.
\end{abstract}

Keywords: Analytic Hierarchy Process (AHP), Climate change, flooding, GIS, recurrence

\section{INTRODUCTION}

Concerns about the environment and climate intensified in the 1970s with awareness of climate change issues and socio-economic consequences (Merle, 2006). According to UNEP/GRID-Arendal (2009) studies, changes in many extreme weather and climate events have been observed since the 1950s. The frequency or intensity of heavy precipitation events has increased in some parts of the world (North America and Europe). This rainfall is often accompanied by unprecedented violent events (IPCC, 2012). However, although climate change experts show a decrease in rainfall in the Sahel, there has been a slight increase since the late 1990s. The work of Wade et al. (2009) and Nouaceur (2020), which show an increase in extreme weather events (heavy rains) in recent years. These intense and localized rainy events are often the result of a few showers interspersed with long drought breaks causing enormous damage to societies.

Villeneuve and Richard (2007), referring to the intensity of precipitation, argue that a severe thunderstorm dumping $300 \mathrm{~mm}$ of water once a month is not the equivalent of $30 \mathrm{~mm}$ of rain every three days, in climatic terms, 
even if the total rainfall is the same at the end of the month. Indeed, the improvement in rainfall in West Africa (Bodian, 2014; Ndong, 2015; Faye et al., 2019; Nouaceur, 2020), has resulted in flooding phenomena thus increasing the vulnerability of the poorest populations. Floods remain a highly topical issue and growing scale in developing countries (Bruckmann et al., 2019). They generally occur in areas already recognized as critical, namely floodplains, which are relatively flat expanses, adjacent to a lake or river and likely to be flooded. Floodplains are subject to changes in water levels and experience rapid and seasonal fluctuations (Wade et al., 2009; Ndiaye, 2016). Floods of natural or anthropogenic origin are linked to global warming, heavy rainfall, overflowing rivers, or marine waters (Ahmad, 2006), anarchic urbanization, poor development, etc. (Nouaceur, 2013; Razafindrakoto, 2014). Flood damage tends to increase over time. It is a scourge that exposes the victim population to total haunting.

The choice of subject is justified by the fact that the floods, affecting both urban and rural areas of Senegal, are observed in all regions of the country, but more worrying in Dakar, St. Louis, Fatick and Tambacounda where they are caused by floods and overflow of rivers. They have been amplified by anthropogenic, topographical, hydrogeological factors besides climatic factors. In addition, the gutters are misused and turned into garbage dumps in the absence of a cleaning, maintenance, and awareness program.

Located in eastern Senegal, the city of Tambacounda is in the eponymous region where it is the capital of the region. It consists of about twenty districts and districts, and is traversed by a fossil valley, the Mamacounda. The city is part of the Sudan climate zone characterized by rains ranging from 600 to $1200 \mathrm{~mm}$ (Sagna, 2007), it is one of the most watered regions in Senegal (Faye et al., 2019). The rainy season, set between June and October, reaches its rainfall peak in August. As one of Senegal's least equipped cities, Tambacounda now suffers from poor urbanization policy and a severe lack of sanitation and development infrastructure. Indeed, it is marked by a near total absence of a sewage and storm water system and household waste collection service. Gravitational rainwater is naturally discharged to the Mamacounda bed (which runs through the city from east to west and plays the main function of natural collection of runoffs).

Because of the silencing and the accumulation of household waste on the minor bed of Mamacounda, irregular occupations and the narrowness of the water crossing points, it is often noted problems of flooding during wintering. After the rain, it is bad weather in Tambacounda. The downpours recorded during the rainy season cause a lot of damage in the city. They limit the movement of people, lead to the destruction of habitats (especially those in banco), hinder economic activities and promote the proliferation of diseases (diarrhea, malaria, etc.).

The aim of this study is to study the problem of flooding in Tambacounda through quantitative, qualitative methods and the use of geographic information systems (GIS) and to analyze the control strategies developed to deal with this phenomenon.

\section{MATERIALS AND METHODS}

\subsection{Study Area}

The city of Tambacounda covers an area of $77.5 \mathrm{~km}^{2}$ and is crossed by a valley (the Mamacounda)) about twenty meters wide (Figure 1). The city of Tambacounda owes its economic and demographic development to the DakarBamako Bamako railway and its railway station. With a population of 25.735 in 25735 1976, it increased from 69.574574 in 2001 to 107.293293 in 2013 (ANSD, 2014). It is one of the poorest and least urbanized regions in Senegal. Health-related diseases are Malaria, Acute Respiratory Infections (IRA)) and Diarrhea (ANSD, 2015).

The geology of the study space is in line with that of the Senegalese-Mauritanian sedimentary basin, whose formation is linked to the opening of the Atlantic. The sedimentary deposits that make up this basin are mesoCenozoic in Quaternary. The city is built on the vast continental terminal. The soils are ferruginous leached. They are mainly composed of clays and sands in the surface layers $(0$ to $20 \mathrm{~cm}$ ) (Faye et al., 2018). The lateral armor that emerges in some parts is covered in places with a thin layer of earth. In terms of physical and chemical properties, these soils have a reduced permeability due to the presence of fine sands and silt in the first horizons but above all a high level of clay at depth. 


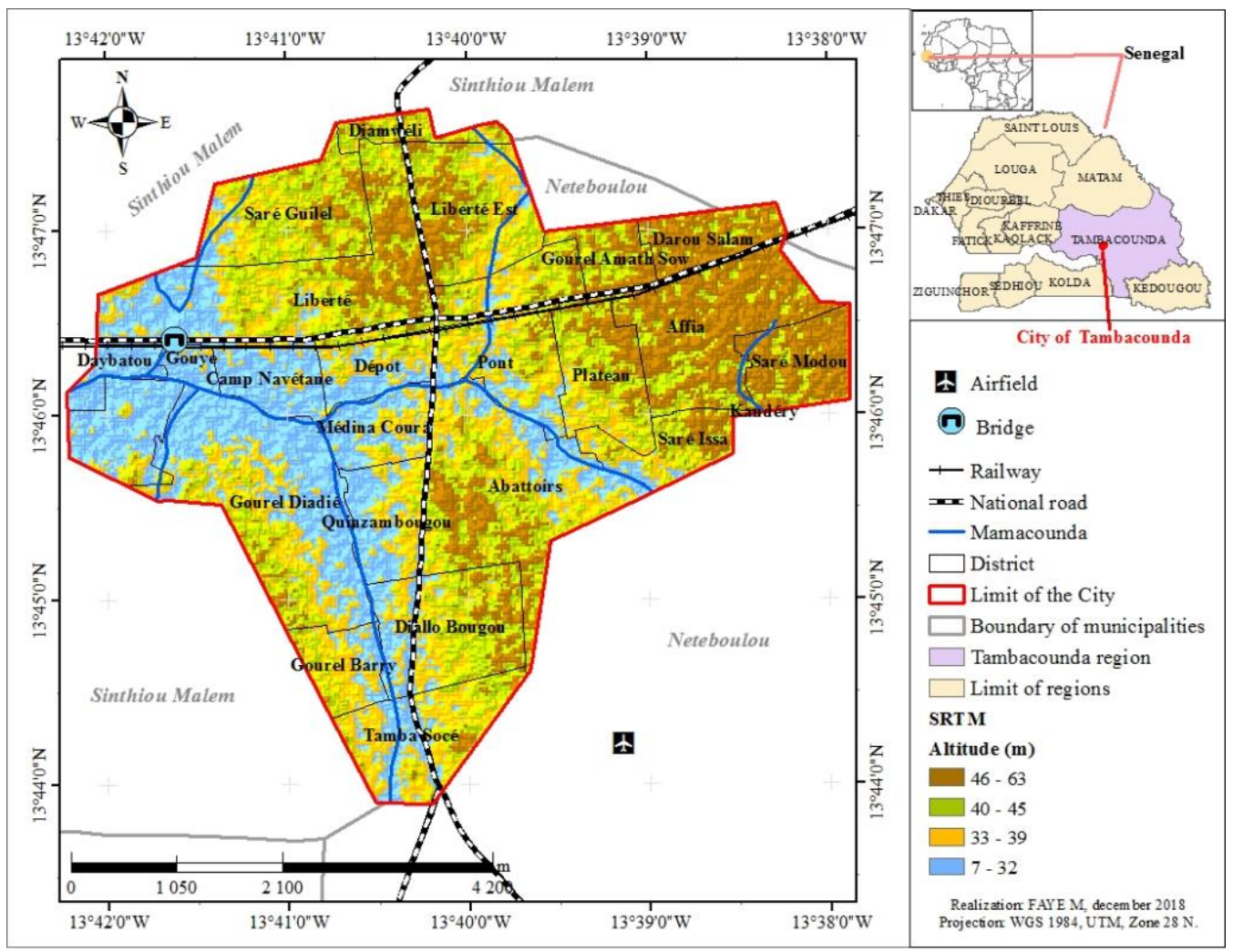

Figure 1 Location of the City of Tambacounda

\subsection{Data}

The rainfall data used ranged from 1950 to 2014 and came from the National Agency for Civil Aviation and Meteorology (ANACIM) in Senegal. They relate on daily, monthly, and annual data. Daily rainfall data for July, August and September are analyzed to better understand the rain events of 1960, 1973, 2003 and 2009 that caused flooding and damage according to field surveys.

Vector data on pedology, geology, the Landsat OLI satellite image (2018), the digital field model SRTM, and climate data extracted from the CHIRPS images in Google Earth Engine are also used. The cross-referencing of this data led to the development of the flood vulnerability map.

This work is also supported by quantitative and qualitative data. A questionnaire is administered to exposed heads of. Chefs of households, especially those who live in neighborhoods along the Mamancounda (Table 1). The people surveyed are randomly selected (all three houses depending on whether they are inhabited).

Interviews with the relevant authorities such as the Mayor of the city, the Governor, the Director of the National Statistics and Demography Agency (ANSD)) in Tambacounda, neighborhood delegates, and some ASC and NGOs working in the field of sanitation have made it possible to better elucidate the main causes of the floods and the strategies developed to remedy this phenomenon.

Neighborhoods

Table 1 Sample of the population surveyed in the targeted neighborhoods

$$
\text { Households Frequency }(\%)
$$

Number

Investigated

\begin{tabular}{l|c|c|c}
\hline Abattoir & 990 & 16 & 50 \\
\hline Camp Navétane & 657 & 10 & 30 \\
\hline Gouye & 189 & 3 & 10 \\
\hline Dépôt & 861 & 14 & 50 \\
\hline Médina Coura & 795 & 12 & 40 \\
\hline Quinzambougou & 812 & 13 & 40 \\
\hline Diallobougou & 278 & 4 & 20 \\
\hline Pont & 835 & 13 & 40 \\
\hline
\end{tabular}


Faye et al.

Analysis of the recurrence of floods in the city of Tambacounda, Senegal, in the context of climate change

\begin{tabular}{l|c|c|c}
\hline Gourel Diadié & 950 & 15 & 50 \\
\hline Total & $\mathbf{6 3 6 7}$ & $\mathbf{1 0 0}$ & $\mathbf{3 3 0}$ \\
\hline
\end{tabular}

\subsection{Methods}

The analysis of rainfall data is based on simple statistical methods (deviation from the 1961-1990 rainfall average, daily and monthly rainfall changes). The average annual values are compared to the 1961-1990 rainfall normal to highlight the rainy anddeficit years.

Saaty's Method of Hierarchical Multi-Criterion Analysis or Analytic Hierarchy Process (AHP) (1977) is applied for the identification and spatialization of flood-risk areas. Indeed, a series of pre-processing is carried out on the soil data, geological and climate data extracted from the CHIRPS images. It is a question of bringing all factors to the same resolution and spatial reference through reprojections and conversions in raster format. Radiometric and atmospheric corrections are made to the satellite images to work with the true reflectance values and extract the frame. The digital field model SRTM was re-drafted in WGS 1984 UTM Zone $28 \mathrm{~N}$ at the same spatial reference as all other factors.

This method is based on the two-to-two comparison of the different factors used. The procedure consists of identifying all the criteria that enter the model and prioritizing them according to their degree of importance, which is, moreover, the weight. The assignment of these weights is based on the scale of Saaty, (1977) and Cirad and Cifor, (2000). Not all factors have the same degree of vulnerability to flooding. This justifies the choice of the weighted overlay of the ArcGIS 10 software that distinguishes the criteria according to their weight. The own values and their vectors indicating the hierarchy of factors are calculated. The importance of one factor to another is assessed by a coherence index (IC) that basically uses its own values. This index assesses the consistency of judgments and provides information on the ordinal and Cardinale importance of the factors to be compared (Cirad and Cifor, 2000).

\section{RESULTS AND DISCUSSION}

\subsection{Physical factors of flooding}

For a multi-criterion analysis model using less than nine factors, the tolerance threshold is set at $10 \%$. After several improvements in the consistency of judgments, we obtained a consistency index of $4 \%$. All factors were weighted and a weighting matrix, so the calculated weights were generated (Table 2). This matrix helps to understand the weight of the different components of flood vulnerability in Tambacounda.

Analysis of Table 2 shows that, apart from rainfall, geology with a weight of 21.24 and pedology (20.97) are the main physical factors of the Tambacounda floods, respectively. The Mamancounda Valley, notched on the Continental Terminal, is the focal point of storm water. From an east-west direction, it also passes south, dividing the city in two (Figure 2). All neighborhoods along this river are highly vulnerable to flooding. This is due to the rapid storm runoff, which is difficult to manage by their suddenness and by the overflow of the river into the surrounding houses (Barczak and Grivault, 2007).

Table 2 Factor Weighting Matrix on the Saaty Scale (1977)

\begin{tabular}{lccccc}
\hline & \multicolumn{1}{c}{ TRTM } & Rainfall & Geology & Settlement & Pedology \\
SRTM & 1 & 3 & $1 / 9$ & $1 / 3$ & $1 / 9$ \\
Rainfall & $1 / 3$ & 1 & $1 / 5$ & 3 & $1 / 5$ \\
Geology & $1 / 5$ & 3 & 1 & $1 / 5$ & $1 / 3$ \\
Settlement & $1 / 3$ & 3 & $1 / 7$ & 1 & $1 / 3$ \\
Pedology & $1 / 3$ & 5 & $1 / 3$ & $1 / 3$ & 1 \\
Weight & $\mathbf{1 6 . 8 4}$ & $\mathbf{2 4 . 9 0}$ & $\mathbf{2 1 . 2 4}$ & $\mathbf{2 0 . 9 7}$ \\
\hline
\end{tabular}

The lowly vulnerable neighborhoods are those located in the far north (Saré Guilèl, Diamwéli and Liberté East) and east (Gourel Amath Sow, Darou Salam, Affia, Kandéry and Saré Modou).

This vulnerability to flooding is also linked to the phenomenon of waterproofing of the soil. The predominance of fine sands and silt in the first horizons ( 0 to $20 \mathrm{~cm}$ ) and the high level of deep clay $(20$ to $40 \mathrm{~cm})$ does not facilitate infiltration (Faye, 2017). Thus, the intense and heavy rains recorded between July and September promote soil saturation and intense rainfall to the low-lying area, the Mamancounda River. Added to this are the floods of the Gambia River that feed the Sandougou, its tributary that gives birth to the Mamancounda. These floods combined 
with storm runoff are the cause of the floods in the city of Tambacounda. Indeed, the recurrence of this phenomenon is intricately linked to the "recovery" of rainfall recorded during the last two decades, to the grip of flood zones and of course to the absence of urban policy and sanitation networks.

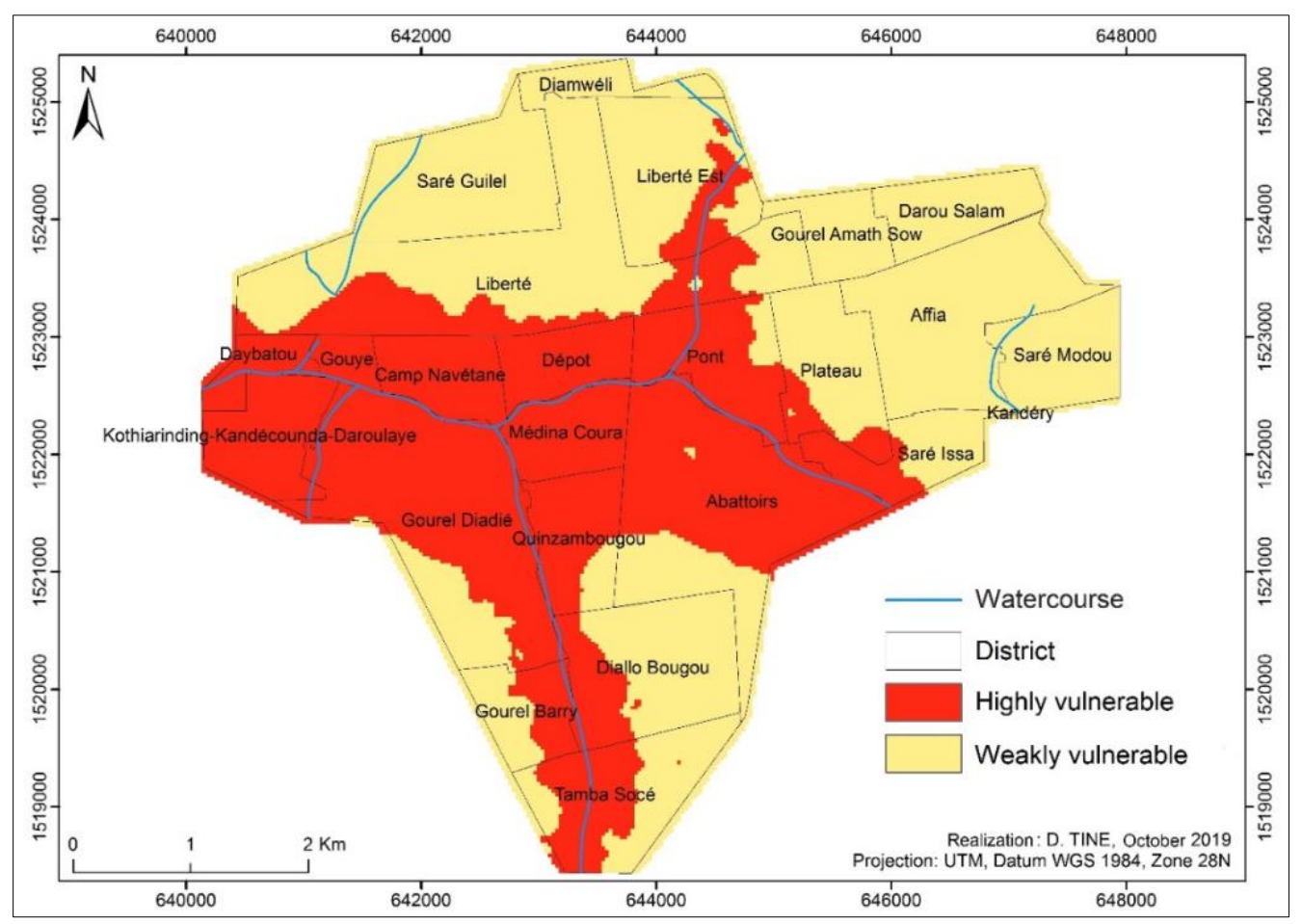

Figure 2 Degree of Neighborhood Vulnerability using the AHP Method

\subsection{Rainfall analysis}

Rainfall volumes varied widely at the Tambacounda station. Like other stations in Senegal, the trend is downward. The 1950s and 1960s remain by far the wettest (Figure 3). After a long period of rainfall decline, a timid recovery was observed in the early 2000s. This improvement in rainfall (alternation of dry and wet years) is often accompanied by extreme weather events (drought, flooding, etc.). The heavy rains and their intensity recorded in the heart of wintering, coinciding with soil saturation, promote runoff to the lower parts (the valley). This accumulation of water combined with flooding leads to overflowing rivers (Ahmad, 2006) and occupation of surrounding houses.

As a reminder, the city of Tambacounda is crisscrossed by the Mamancounda valley, which is an extension of the Sandougou, a tributary of the Gambia River. The floods of the latter are mainly the cause of the disastrous floods recorded in this city.

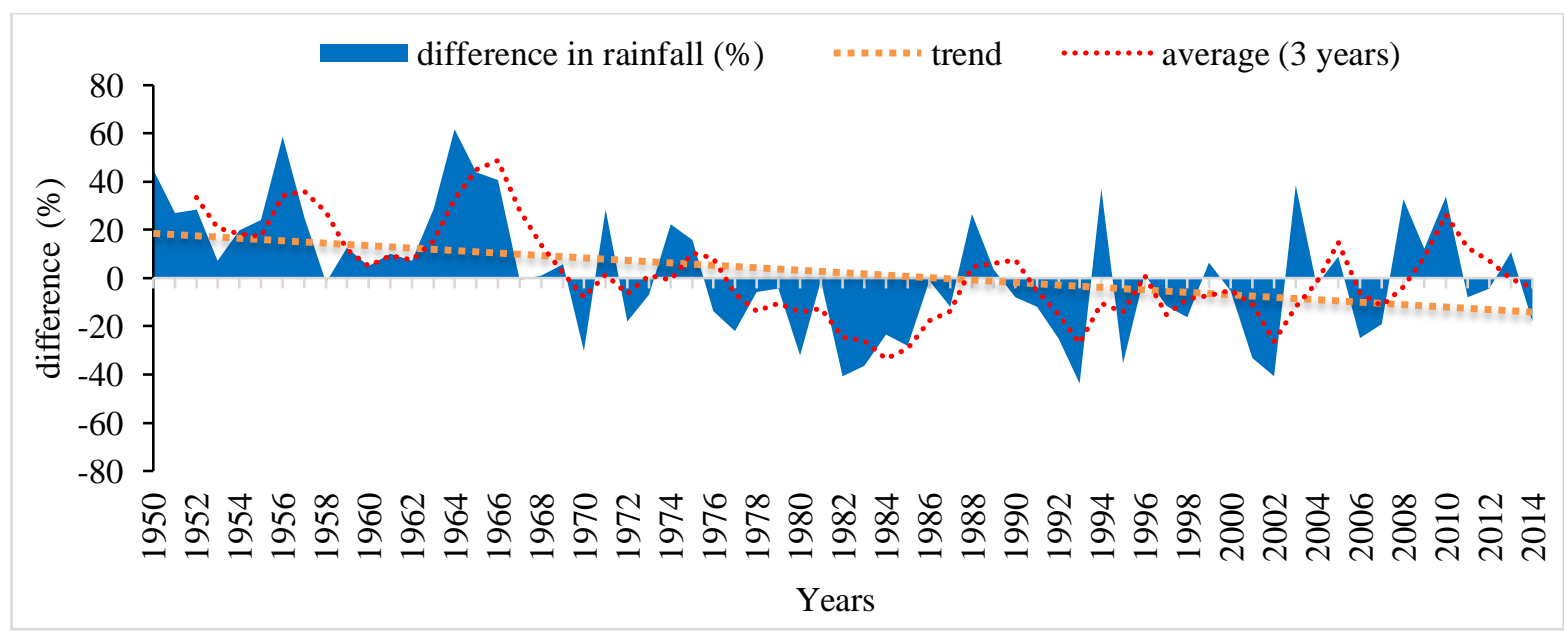

Figure 3 difference in rainfall (\%) from normal 1961-1990 at Tambacounda synoptic station during 1950-2014 
According to survey results, $95 \%$ of the population say that flooding occurs in the city between July and September. These months, the rainiest of wintering, are marked by the frequency and intensity of the rains. During this period, the region records rainfall related to the Intertropical Convergence Zone (ICZ) (characterized by regularity of rains) in place of the grain lines (intense but irregular rains) (Faye, 2017). The analysis of Figure 4 shows the importance of the rainfall volumes recorded during these three months (July, August and September). The water supplies of these months contribute greatly to the floods of the city. With reduced permeability and soil saturation, storm water flows towards the Mamancounda River, promoting intense water erosion, transport of fine particles and sips of the valley's minor bed. This causes the river to overflow, the roads to be invaded and peripheral houses to be invaded.

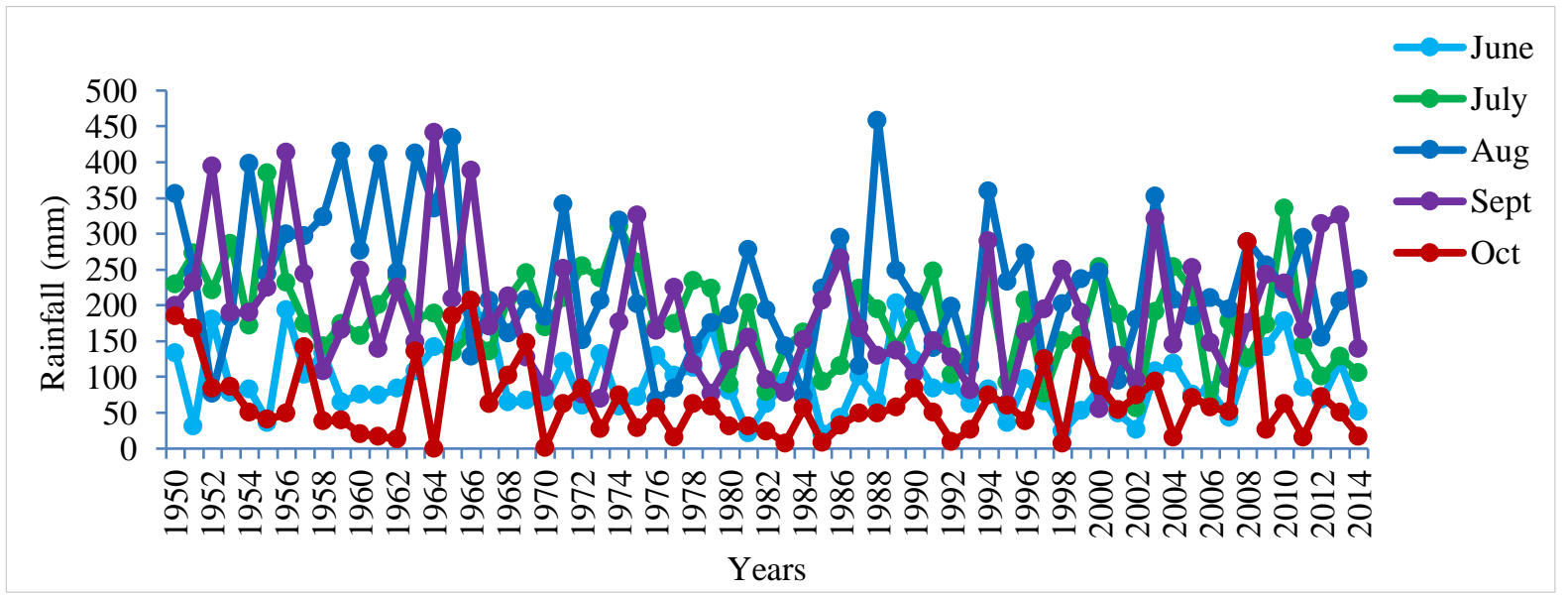

Figure 4 Monthly rainfall (June, July, August, September, and October) at Tambacounda station for the period 1950 - 2014

Flood damage is environmental, socio-economic and health. They affect the population, destroy habitats and infrastructure, trigger malaria and diarrheal diseases, and limit the movement of people.

The rainy season, which is a source of hope for the Senegalese peasant, is a blue fear for the urban population. Rainfall in July, August and September is the most feared. The population remembers the rain events of 1960, 1973, 2003 and 2009 and report that the 2003 floods were more destructive. Analysis of daily rainfall data (Figure 5) for July, August and September in those years shows the drop in large amounts of water, sometimes exceeding $40 \mathrm{~mm}$ in one day. The most significant rain events, exceeding $60 \mathrm{~mm} /$ day, concern August 11, 1960, July 8, 1973, August 16, 1973, July 25, 2003, and August 22, 2003. Field surveys showed that the rain events of 2003, with an average annual rainfall of $1066 \mathrm{~mm}$, affected more than $80 \%$ of households. Homes, streets, and fields were flooded with storm water. This situation had led to massive displacement of families and huge damage estimated at billions of CFA francs (Faye et al., 2019).

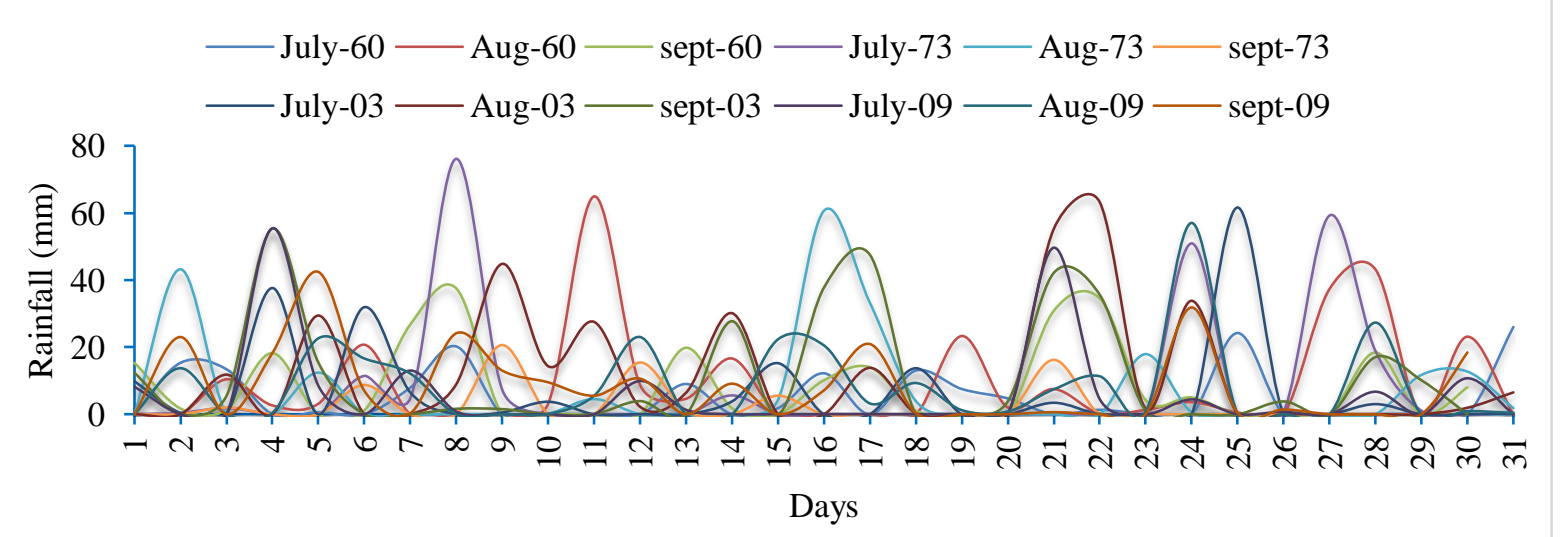

Figure 5 daily rainfall volume in July, August, and September at the Tambacounda station during the 1960s, 1973, 2003 and 2009

Flooding, which has been recurring in recent years, is growing in the city. Homes near the Mamancounda Valley are the most exposed. After each downpour, we see habitat destruction and sometimes loss of life. Some outlying areas such as Diallobougou, Gouye, Plateau, Saré Guilèl, Gourel Ponang and Abattoirs complement each other during 
wintering, due to lack of road infrastructure. In the populous Pont district, with the dilapidated bridge that serves as a crossing, the population wades through the waters or makes great detours to return to their homes.

The proliferation of water points therefore promotes the development of mosquitoes and other larvae that carry diseases such as malaria, cholera, diarrhea... Naturally occurring, floods are amplified by anthropogenic actions.

\subsection{Anthropogenic factors of floods}

\subsubsection{The anarchic and spontaneous occupation of space}

Anarchic occupation of space and inadequate sewerage systems are factors aggravating flooding (Dhaher, 2011; Ndoye, 2016). The urbanization of the city of Tambacounda accelerated after the 1990s without planning policies. Waterproofed surfaces are found upstream of the valley because of population growth and urban sprawl. This situation has caused significant and very violent runoff, due to increased flow transfer speeds (Daoud, 2013), on areas occupied by dwellings.

It should be noted that Tambacounda is a city marked by a horizontal development of the building, unlike the Senegalese capital (Dakar) where the trend is vertical due to lack of space. The high concentration of habitats around the valley can also be explained by socio-economic activities such as gardening, rice farming and market gardening practiced in this site. This has led many people (35\%) to settle there. For others $(65 \%)$, they settled because they thought the valley was dry after years of drought. Thus, the timid "recovery" of the rains in recent years has had a heavy impact on these households.

\subsubsection{Hasty Urbanization}

The ambition to find a home in the city of poor households is also a determining factor in the rampant and anarchic urbanization of developing countries. The way the land is occupied, the type of habitat and even the names of the neighborhoods can be used to categorize the social groups occupying it. Residential neighborhoods, well-off and equipped with a sanitation system, are opposed to poor, oil-stained neighborhoods that lack everything. This makes Oumarou and Oumarou (2017) say that "beyond the problems of technical and administrative management, floods reveal social inequalities that are expressed through a discriminating occupation of urban space." Low-income households usually settle on non-aedificandi land whose consequences can be disastrous (Issaka and Badariotti, 2013; Bruckmann et al., 2019). This urbanization dynamic is observed in almost all the cities of Senegal. It is the origin of the so-called "irregular" undeveloped neighborhoods characterized by a lack of sewerage system, the frequency of flooding and a notorious unsanitary condition.

\subsubsection{Poor management of household waste}

Flooding in Tambacounda city is also linked to the management of urban solid waste. As a reminder, there is no effective waste disposal system in the city. The Mamancounda Valley is considered a garbage dump for some households (25\% of respondents) (Figure 6). However, the accumulation of solid waste is an obstacle and therefore slows down the flow of storm water. Solids Waste sometimes creates traffic jams at the bridges (as a bridge) that cross the stream. This exposes the riverside neighborhoods to flooding during heavy rains. This situation is most pronounced in the Pont, Medina Coura, Depots, Abattoirs and Gouye neighborhoods. Flooding during downpours causes extensive property damage and sometimes loss of life in these neighborhoods. This is the case of the rain of Thursday, June 22, 2017 (102 $\mathrm{mm}$ ) which had led to the drowning of a man at the height of the railway bridge (Pont District) and the relocation of twenty families or 81 people to schools by the municipality.

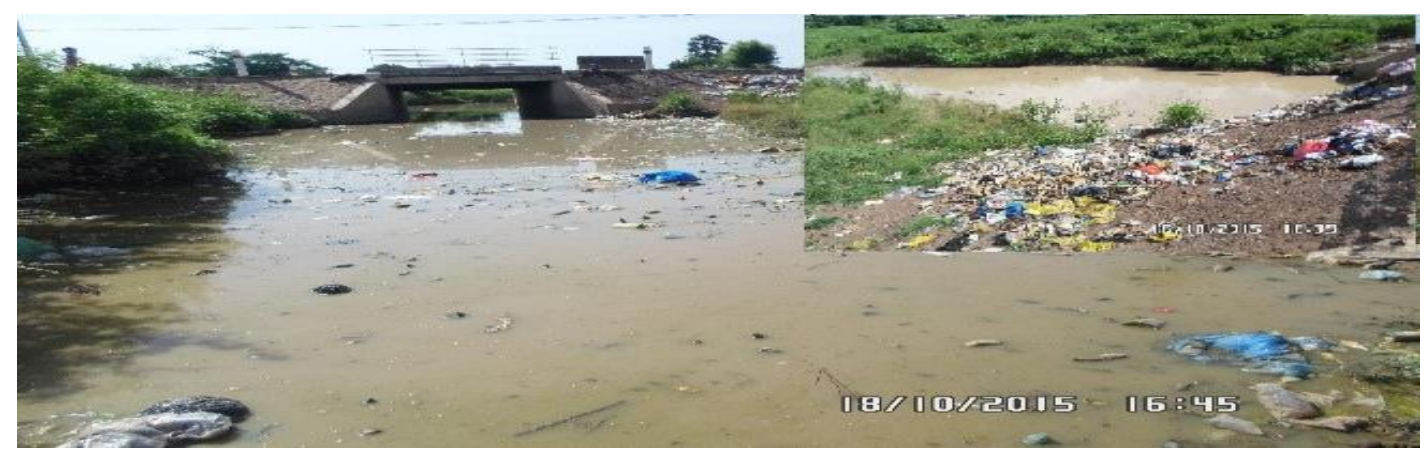

Figure 6 Presence of waste in the Mamancounda Valley and transformation of water into mud at the bridge of the Abattoirs district on National Highway 7. Source: Faye, 2015 
Faye et al.

Analysis of the recurrence of floods in the city of Tambacounda, Senegal, in the context of climate change

Faced with this situation, actions are being taken by the population to deal with the floods in the city of Tambacounda.

\subsection{Flood control strategies}

Flood began to be incorporated into urban development policies in the 2000s with the ORSEC plan (Wade \& al., 2009). Aware of the socio-economic impacts, state authorities are increasingly investing in flood management to reduce the vulnerability of the population.

Thus, institutional measures are taken: the adoption of urban development plans; creation of the National Agency for The Fight against Floods and slum belt; development of storm water retention ponds, etc. However, these state efforts are not widespread at the national level. Most strategies are focused in the capital Dakar; others are still pending because they are not approved. Flood management should be summarized in three phases: pre-flood preparedness; assistance and evacuation; and finally, post-flood assistance and resettlement (Ahmad, 2006; Defossez, 2011; Moulin et al., 2017; Oumarou. and Oumarou, 2017). In Tambacounda, flood control techniques are rudimentary. The population itself has faced the floods with the available resources, while waiting for humanitarian aid from the state and NGOs. Strategies developed revolve around filling ravines and low parts (45\% of responses), sandbags (40\%) to block storm water runoff to homes and dig channels (15\%) to facilitate runoff to the Mamancounda River.

We also note in the fight against floods, the intervention of the Integrated Waste Cleanup and Recovery System (SINVAD) in collaboration with the Belgian municipality of Sint-Niklaas. The stated ambition is to combat unsanitary conditions through the best waste collection and management strategies to promote public health to prevent diseases related to dirt and garbage, stresses the municipality. This project is active in the transformation of waste into compost and the development of market gardening around the Mamancounda. To this end, Neighborhood Development Committees (CDQs) are created for waste collection. Since 2010, SINVAD has expanded into several neighborhoods (about ten) by equipping them with cleaning equipment. This material is distributed to the CDQ beneficiaries who in turn provide households with garbage cans. This community approach and this framework for the proximity of households are the levers on which SINVAD relies to change the behavior of the population. In the outreach component, SINVAD organizes tea debates, radio and local television programs, public information meetings, and human investments commonly referred to as «sét sétal» as part of a participatory approach. This has reduced the wild deposits of garbage in the Mamancounda.

To allow people to move freely during the rainy season and facilitate storm runoff, bridge clearing operations (Figure 7) that often cause flooding and drowning (Figure 8) are carried out annually by the municipality. For example, in 2014, it claims to have invested 55\% of the expenditure on the city's sanitation.

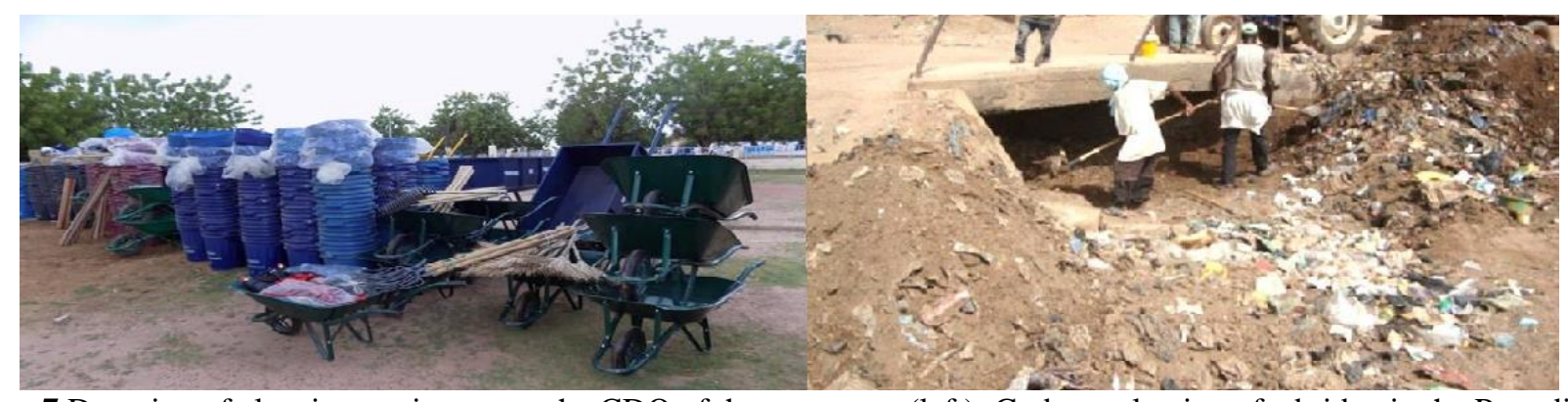

Figure 7 Donation of cleaning equipment to the CDQ of the commune (left); Garbage clearing of a bridge in the Pont district to promote the flow of storm water (right). Source: Alkuma.www.flash.info, 2015.

Figure 8 represents the city's remediation plan, defined in 2006 by the relevant authorities for 2024. Its role is to evacuate all liquid waste (worn water, rainwater) from the city center to the sewage treatment zone on the periphery. Liquid waste, after collection and transport, is safely filtered, purified, and dumped into the wild. This remediation plan is proving to be economically beneficial, as not all households can afford to use the costly sludge. It should be noted that the interventions of the National Sanitation Office of Senegal (ONAS) are more focused in the city of Dakar (Senegalese capital), whereon the one hand records $576 \mathrm{~km}$ of wastewater networks, 37 pumping stations and a wastewater treatment plant; on the other hand, $89 \mathrm{~km}$ of drainage gutters and 2 storm water pumping stations. This is not the case in Tambacounda, which does not have a spent and storm water drainage system or a sewage treatment plant.

This wastewater treatment project in Tambacounda Is also affects the neighborhoods such as Liberté, Pont, Dépôt, Médina Coura, Camp Navétane and Gouye. It is funded by the State of Senegal and the West African Development Bank (BOAD) to significantly improve people's living and health conditions. According to the director of ONAS, 
there are 1,500 sewer connections, a pumping and sewage plant, a sludge treatment plant, and the construction of about 50 solar buildings.

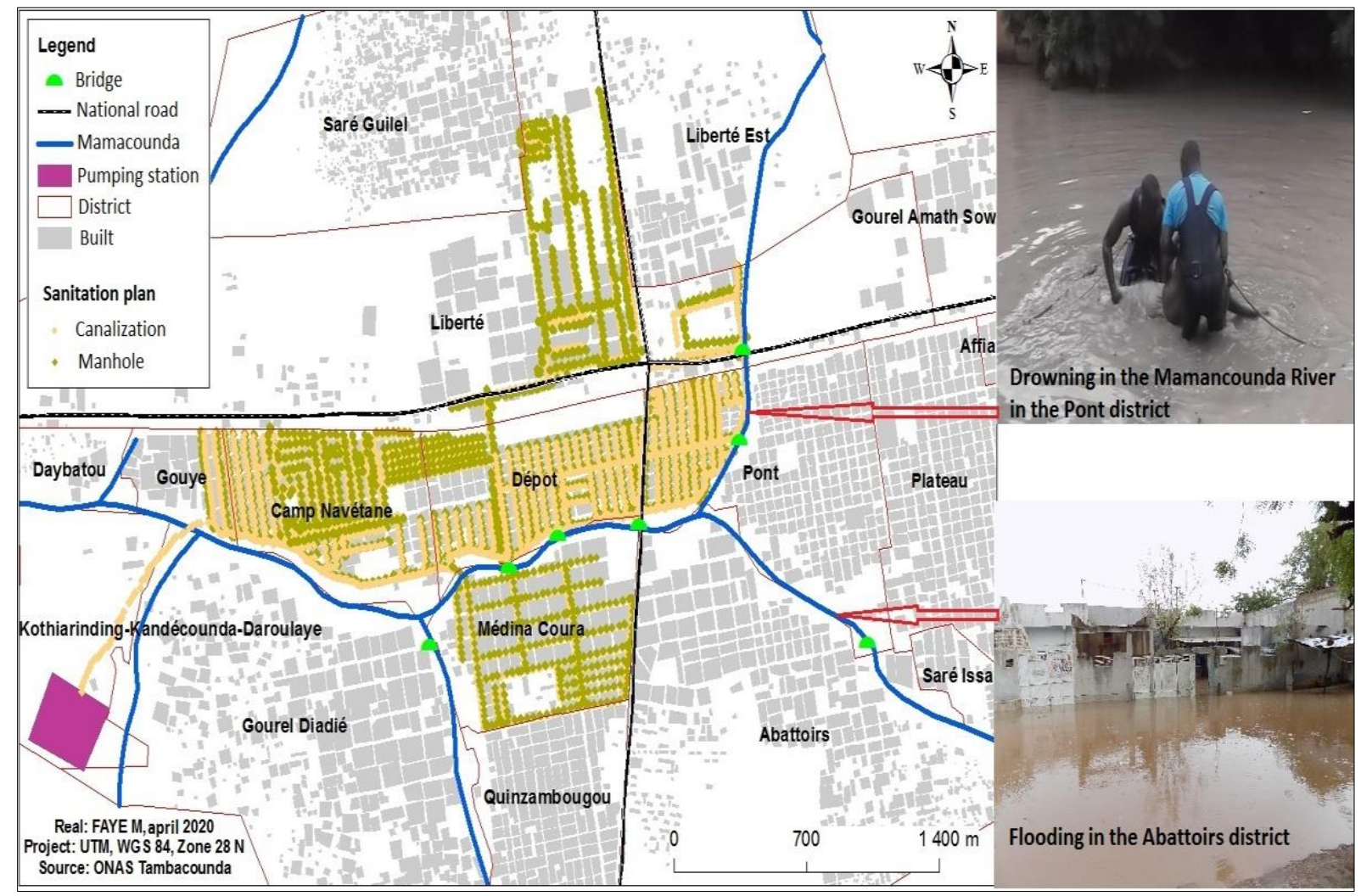

Figure 8 Remediation plan for a few neighborhoods, completed in 2006 by 2024

The route followed by the wastewater management plan is also suitable for rainwater drainage (Figure 10) as this plan focuses on the total management of liquid waste.

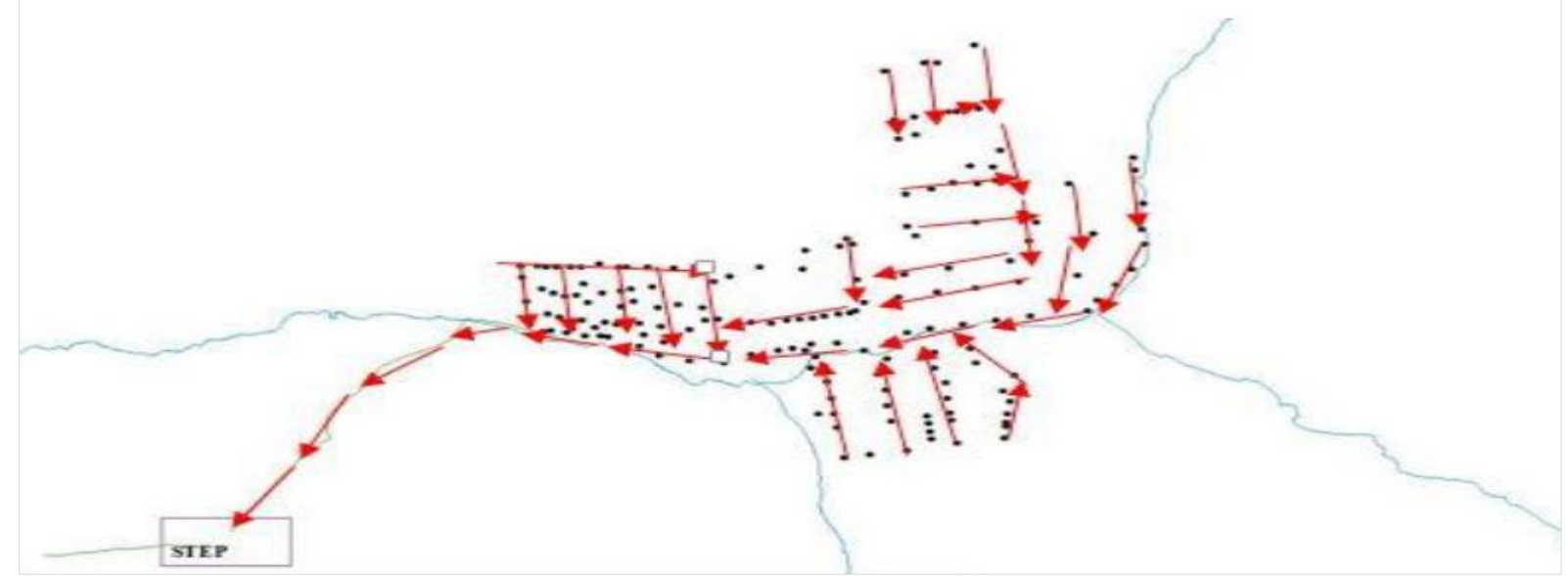

Figure 9: Wastewater and storm water collection route (Diop, 2019)

\section{DISCUSSION}

There is no doubt that rainfall in sub-Saharan Africa decreased drastically in the late 1960s. Recent studies (Bodian, 2014; Descroix et al., 2015; Ndong, 2015; Faye et al., 2019) and climate data analyses have revealed that despite the "recovery" of rains reported by some researchers in recent years (Nouaceur, 2020), the 1950s and 1960s are by far the most regularly watered and wet. This period of "recovery" rainfall, very contrasting, alternating years of heavy rainfall and dry years (Faye et al., 2018). Droughts in 1970 and 1980 had a heavy impact on rural Africa and encouraged the concentration of the population in cities in search of better living conditions. These climatic 
events have exacerbated the rural exodus, the occupation of flood-risk areas and the proliferation of slums. This situation, observed in virtually all the cities of Senegal, is the result of the repetitive floods recorded in recent years.

Increased rainfall is indexed as the main natural factor (Wade et al., 2009; Thomas-Maret et al., 2012; Diop et al., 2014) explaining the floods. If so, why were they not frequent and more devastating during the wetter years (1950 and 1960)? It is difficult, from a scientific point of view, to attribute these disasters to climate change alone (Bertoni, 2006). They are a way of unveiling the ineffectiveness of public policies on urban planning (Oumarou. and Oumarou, 2017). According to Bertoni (2006), floods are compounded by anthropogenic actions such as inadequate use of urban space, a lack of water management master plans specifically dedicated to the urban drainage system, and a lack of intervention plan and political will. For example, despite the recurrence of floods and the damage caused at the national level, the strategies developed have been in vain. In Dakar, the city most affected, several urban planning plans (Dakar 2001's master plan for urban planning (PDU); Dakar PDU by 2025; Master Plan for the Planning and Safeguarding of The Niayes and Green Zones of Dakar developed in 2005 (PASDUNE)) were initiated without effective application because not approved for lack of political will (Diongue, 2014). This is supported by the fact that Tambacounda the only sewage and storm water disposal plan, drawn up in 2006 for 2024, has always remained at an embryonic stage. To date, no serious and reliable measures have been taken to effectively combat flooding.

Apart from local waste management initiatives, the strategies developed are disaster assistance. The latter, as a result of the floods, are temporarily relocated to schools and receive food and material aid. These donations are mainly made by the Town Hall (75\%), the State (10\%), NGOs (Caritas, La Lumière) (10\%) and men of good will (5\%). They include free distribution of food (rice, oil, soap, sugar, bleach) and cash transfer operations. Non-food aids consist of impregnated mosquito nets, household materials (basin, buckets), mattresses, blankets, etc. These grants are estimated at millions of CFA francs. For example, after the floods of 2014, 530 family leaders had received financial support of 15.3 million CFA francs from the town hall and 5.6 million FCFA from the state for a total of 20.9 million CFA francs about 31908 euros.

Flood management reflects regional and toll inequalities. Urban hygiene and sanitation policies are limited. Unlike the Senegalese capital (Dakar), where several programs to combat floods and rehousing victims in exonerated environments have been launched by the State, there is not one such in Tambacounda. After the floods, $15 \%$ of families leave their homes to live with neighbors or relatives while waiting for the water to recede from the living areas. A significant proportion of the population, $85 \%$, manages to remove storm water from their homes and is sure that they can be submerged again. Indeed, this individual and prosaic action of struggle often causes conflicts between neighbors. Trenches dug to facilitate the flow of storm water sometimes create flooding in other homes or accidents.

This clear lack of a common public flood policy and sustainable and effective strategies only exacerbates the floods in the city of Tambacounda in the context of climate change. In addition to its economic and material impacts, floods affect the public health of the population. The stagnation of rainwater mixed with sewage and garbage, promotes the proliferation of larval deposits and the constant presence of pathologies (Diop, 2014; Razafindrakoto, 2014). In 2015, 702 cases of malaria and 1,452 cases of diarrhea were recorded in the Health District of the Depot district alone. The highest number of cases of malaria and diarrhea is reported between August and December.

In the end, concrete steps must be taken to address this phenomenon. To do this, the State, the relevant authorities, and development partners need to be more involved in the fight against floods. The implementation of the ONAS wastewater and storm water remediation plan and the framing of local strategies would reduce the vulnerability of the population to flooding and mitigate the damage.

\section{CONCLUSION}

The increase in rainfall over the past two decades is increasingly exposing the population of Tambacounda to flooding. These are accentuated by the Mamancounda River that crisscrosses the center of the city. The dripping water accumulates there while causing intense water erosion in their path. While some index the rain as an explanatory element of the floods, the occupation of the environment remains. Since the droughts of 1970 and 1980, marked by a marked decline in yields and famine, the rural population has continued to concentrate in the city in search of better living conditions. This situation, combined with a lack of urban planning policy in Tambacounda, has led to urban sprawl and the occupation of vulnerable environments. Floods that often cause significant property damage and sometimes loss of life.

Field studies have shown that, despite the recurrence of this phenomenon, no concrete action to combat, protect or prevent is developed by either the State or the competent authorities. According to the respondents, after each flood, the local authorities go around the neighborhoods and houses affected to see the damage and to make promises that are never kept. The initiatives carried out on the ground, on a limited basis, are carried out by the population. 
Faced with this timid "recovery" in rainfall, it is urgent to develop strategies to reduce the vulnerability of the population to floods. To do this, participatory measures must be adopted with the help of all stakeholders. The state, for its part, must take urgent measures. These include dredging and channeling the water stream, constructing protective, implementing a functional sanitation policy, regulatory flood risk management tools and rehousing households around The Mamancounda in exonerated environments.

Conflict of Interest: We declare that there is no conflict of interest.

\section{REFERENCES}

Agence Nationale de la Statistique et de la Demographie. (2014). Recensement général de la population et de l'habitat, de l'agriculture et de l'élevage (RGPHAE) de 2013. Rapport provisoire, $36 \mathrm{p}$.

Agence Nationale de la Statistique et de la Demographie. (2015). Situation économique et sociale régionale de Tambacounda en 2013. Agence Nationale de la Statistique et de la Démographie (ANSD), 126 p.

Ahmad, Q.K. (2006). Changement climatique, inondations et gestion des crues : le cas du Bangladesh. Cairn.info pour La Découverte, Hérodote, ${ }^{\circ}$ 121, 2e trimestre, pp 73-94. https://www.cairn.info/revue-herodote-2006-2page-73.htm

Bertoni, J.C. (2006). Inondations urbaines en Amérique Latine: réflexions sur le rôle des facteurs de risque. Frontiers in Flood Research / Le point de la recherche sur les crues (IAHS Publ. 305), pp 123-141.

Bodian, A. (2014). Caractérisation de la variabilité temporelle récente des précipitations annuelles au Sénégal (Afrique de l'Ouest). Revue Physio-Géo, 8, 1, 297-312.

Bruckmann, L., Amanejieu, A., Zogning Moffo, M.O. \& Ozer, P. (2019). Analyse géohistorique de l'évolution spatiotemporelle du risque d'inondation et de sa gestion dans la zone urbaine de Douala (Cameroun) », pp 91-113. Physio-Géo, 13, 91-113. http://journals.openedition.org/physio-geo/8038

Barczak, A., Grivault, C. (2007). Système d'information géographique pour l'évaluation de la vulnérabilité au risque de ruissellement urbain. Session 1.2, NOVATECH, pp 139-146.

CIRAD and CIFOR. (2000). Application de l'analyse multicritère à l'évaluation des critères et indicateurs ; Manuels de critères et indicateurs pour la gestion durable des forêts. Librairie du CIRAD/France, $74 \mathrm{p}$.

Daoud, A. (2013). Retour d'expérience sur les inondations dans l'agglomération de Sfax (Tunisie méridionale) de 1982 à 2009 : de la prévention à la territorialisation du risque. Revue Géographique de l'Est, vol. 53 / 1, 2, 16p.

Descroix, L., Diongue-Niang, A., Panthou, G., Bodian, A., Sane, Y., Dacosta, H., Malam Abdou, M., Vandervaere, J.P., Quantin, G. (2015). Evolution récente de la pluviométrie en Afrique de l'Ouest à travers deux régions : La Sénégambie et le bassin du Niger Moyen. Climatologie, 12, 25-43.

Defossez, S. (2011). Réglementation vs conscience du risque dans le processus de gestion individuelle du risque inondation », Géocarrefour, Vol. 86, 3, 4, pp 281-290. http://journals.openedition.org/geocarrefour/8499

Dhaher, N. (2011). Production du sol urbain et vulnérabilité aux inondations : l'exemple de la cité Sidi Hcine Essijoumi en Tunisie. Confins, 12, Revue franco-brésilienne de géographie, 14 p. http://journals.openedition.org/confins/7129

Diongue, M. (2014). Périphérie urbaine et risques d'inondation à Dakar (Sénégal): le cas de Yeumbeul Nord. ESO, travaux \& documents, $\mathrm{n}^{\circ} 37$, pp 45-54.

Diop, A., Niang, C.I., Mbow, C., Diallo, A.D. (2014). Etude de la vulnérabilité de Thiaroye sur Mer aux inondations : facteurs et effets. Nouvelle Série, $\mathrm{n}^{\circ} 18$, pp 186-200.

Diop, M. (2019). Apport de la Géomatique dans la gestion des déchets liquides pour la commune de Tambacounda. Mémoire de BTS, EDD, Sénégal, 96 p.

Faye, M. (2017). La variabilité climatique des années 1950 aux années 2010 et ses impacts sur les ressources naturelles dans la Région de Tambacounda (Sénégal). Thèse de doctorat unique en géographie, UCAD, Dakar, $471 \mathrm{p}$.

Faye, M., Fall, A., Faye, G., Van Hecke, E. (2018). La variabilité pluviométrique et ses incidences sur les rendements agricoles dans la région des Terres Neuves du Sénégal oriental. Revue belge de géographie, $17 \mathrm{p}$. http://journals.openedition.org/belgeo/22083.

Faye, M., Fall, A., Tine, D., Faye, C.S., Faye, B., Ndiaye A. (2019). Evolution pluvio-thermique de 1950 à 2013 au Sénégal oriental : cas de la Région de Tambacounda. Int. J. Adv. Res. 7(12), 270-287. http://dx.doi.org/10.21474/IJAR01/10152.

IPCC Climate Change (2012). Gestion des risques d'évènements extrêmes et des catastrophes pour faire progresser adaptation au changement climatique. Rapport spécial, GIEC, Genève, Suisse, 28 p. 
Issaka, H. \& Badariotti, D. (2013). Les inondations à Niamey, enjeux autour d'un phénomène complexe. Les Cahiers d'Outre-Mer, pp 295-310. http://journals.openedition.org/com/6900

Merle, J. (2006). Océan et climat. Editions IRD, Paris, 222 p.

Moulin, C., Faytre, L. \& Bauduceau, N. (2017). Réduire la vulnérabilité des territoires aux inondations : évaluer pour agir. Cairn.info pour Irstea, Numéro 23, pp 12-17. https://www.cairn.info/revue-sciences-eaux-et-territoires2017-2-page-12.htm

Ndiaye, M.L., Traore, V.B., Toure, M.A., Sambou, A., Diaw, A.T., Beye, A.C. (2016). Detection and ranking of vulnerable areas to urban flooding using gis and asmc (spatial analysis multicriteria): a case study in Dakar, Senegal. International Journal of Advanced Engineering, Management and Science (IJAEMS), 2(8), 1270 1277.

Ndong, J.B. (2015). Evolution climatique récente sur le littoral sénégalais. Revue de Géographie de l’Université de Ouagadougou, 4 (2), 151-168.

Ndoye, A. (2016). Les inondations et leurs impacts dans la Commune de Tambacounda. Mémoire de master 2, géographie, UCAD, Sénégal, 109 p.

Nouaceur, Z., Gilles, S. (2013). Changements climatiques et inondations urbaines au Sahel - études de cas: Nouakchott (Mauritanie), Ouagadougou (Burkina Faso). Lomé, 10 p.

Nouaceur, Z. (2020). La reprise des pluies et la recrudescence des inondations en Afrique de l'Ouest sahélienne. Physio-Géo, 15, 89-109.

http://journals.openedition.org/physio-geo/10966

Oumarou, H., Oumarou A. (2017). La gestion humanitaire des inondations dans une commune de Niamey. Rapport IIED, London, $39 \mathrm{p}$.

PNUE/GRID-Arendal (2009). Climat en Péril : Guide grand public des derniers rapports du GIEC. PNUE, GRIDArendal et SMI, $59 \mathrm{p}$.

Razafindrakoto, J.L. (2014). Résilience des habitations aux inondations en milieu urbain : le cas d'Andohatapenaka, un quartier de la ville d'Antananarivo. Éthique et économique/Ethics and Economics, 11 (1), 96-108.

Sagna, P. (2007). Caractéristiques climatiques, in Atlas du Sénégal. Paris, éditions Jeune Afrique, 66-69.

Saaty, T.L. (1977). A scaling method for priorities in hierarchical structures. Journal of mathematical Psychology, $\mathrm{N}^{\circ} 15,234-281$.

Thomas-Maret, I., Bleau, N., Fuamba, M., Kadi, S., Abasolo, P.S. \& D-Dutil G. (2012). Vulnérabilité sociétale et territoriale aux inondations des communautés de la rivière des Prairies, Montréal dans le contexte des changements climatiques : enjeux et méthode d'analyse. IS.RIVERS, A2 - DEBORDEMENTS / FLOODS, 3 p.

Villeneuve, C., Richard, F. (2007). Vivre les changements climatiques : réagir pour l'avenir. Editions Multi Mondes, $449 \mathrm{p}$.

Wade, S., Faye, S., Dieng, M., Kaba, M., Kane, N.R. (2009). Télédétection des catastrophes d'inondation urbaine : le cas de la région de Dakar (Sénégal). Journées d'Animation Scientifique (JAS09) de l'AUF, Alger, 5 p. 